\title{
Mihályi Péter
}

\section{A gyermekvállalás batárbasznai és batárköltségei}

ÖsszeFoglaLó: Amikor a családok ex ante döntést hoznak a gyermekvállalásról akkor meredeken csökkenő határhaszonnal számolnak. Vagyis az 1. gyermek születése óriási boldogsággal (haszonnal) jár, ehhez képest a 2. és további gyermekek hasznossága csökken. Történelmileg ez nem volt mindig így: a szegény társadalmakban inkább az a megfontolás dominált, hogy a gyermekek már kiskorukban is tudnak dolgozni. Így a határhaszon alig-alig csökken, ott van az átlaghaszon környékén. A gyermekvállalás társadalmi haszna alig-alig befolyásolja a családokat, jóllehet minden egyes megszülető gyermek társadalmi hasznossága közel azonos. Ez magyarázza, hogy a politika formálói szeretnék a családokat minél több gyermek vállalására ösztönözni. Végkövetkeztetésünk az, hogy a tanulmányban figyelembe vett tényezők keretein belül nincs egyensúly, a stabil tendenciák nem vezetnek társadalmi optimumhoz. A népességfogyás és az elöregedés nemzeti keretek között nem szüntethetố meg, sôt számottevően nem is enyhíthető, akármilyen nagy pénzösszeggel is próbálja az állam csökkenteni a gyermekvállalás egyéni költségeit. ${ }^{1}$

KuLcsszavak: határhaszon, határköltség, fogamzásgátlás, termékenység, humán tôke

JEL-KódoK: J13, J22, J24

D0l: https://doi.org/10.35551/PSZ_2019_4_5

„Flóra, csináljunk gyereket, hadd vessen cigánykereket" József Attila: Töredékek

A modern kor innovációi közül hármat fontos kiemelni: (1) kifejlődtek a népesség túlnyomó részét lefedő nyugdíjrendszerek, (2) az életszínvonal növekedésének és a medicina fejlödésének köszönhetően az anya-, a csecsemő- és gyermekhaladóság töredékére csökkent, nőtt a születéskor várható élettartam, (3) az orális fogamzásgátló tabletta megjelenésével biztonságossá vált a családtervezés. A mából vissza-

Levelezésie-cím: peter@mihalyi.com tekintve triviális, de az úttörőnek mondható bismarcki nyugdíjrendszer kigondolóinak aligha jutott eszébe, hogy a garantált öregségi nyugdíj antinatalista hatású: ha valaki elégséges nyugdíjra számít, akkor „nincs szüksége”, hogy idős korában gyermekei tartsák el. Éppen ezért a nyugdíj nagyságának megállapítása és a felnevelt gyermekek számának összekapcsolása a nemzetközi irodalomban régóta napirenden van (Demény, 1987). ${ }^{2} \mathrm{E}$ tárgyban már volt 2012-ben egy színvonalas szakmai konferencia Magyarországon. A témában megjelent tanulmánykötetben (Kovács, 2012) már kifejtettem véleményemet. Akkor írásom címe egészen pontosan visszatükrözte mondanivalóm lényegét: „Húsz érv a nyugdíj és a gyermekszám összekapcsolása ellen”. Véleményem 
azóta sem változott jottányit sem: nem gondolom, hogy a nyugdíjrendszeren keresztül számottevően lehetne ösztönözni a gyermekvállalást, sőt - mint majd e tanulmányból ki fog derülni - abban a kérdésben is szkeptikus vagyok, hogy lehetséges-e egyáltalán a születésszámot növelni bármiféle állami támogatással.

E tanulmány nem továbbfejlesztése korábbi írásomnak, hanem logikai hátralépés, kísérlet egy előzetes kérdés megválaszolására: „miért nem vállal a magyar családok túlnyomó többsége immáron fél évszázada harmadik, negyedik, ötödik stb. gyermeket?" Cikkem legföbb újdonsága az, hogy a gyermekvállalásról szóló döntéseket a határhasznok és a határköltségek öszszevetése alapján fogja elemezni - méghozzá nagyon hosszú távon, az elméletileg lehetséges gyermekvállalási kor kezdetétől a halál bekövetkeztéig, tehát hozzávetőlegesen a szülők 20. életévétől a 80. életévükig. Az elemzés végén ki fog derülni, hogy szemben a hagyományos egyensúlyi modellekkel - például Becker (1976) - a mi modellünkben az egyéni (családi) és a társadalmi érdek ellentéte nem oldható fel, az időben stabil tendenciák nem vezetnek társadalmi optimumhoz, a demográfiai egyensúlyt biztosító 2,05 teljes termékenységi arányhoz (TTA). Nyilvánvalóan a modell bővítésével a mai magyar helyzet leírása még tovább árnyalható lenne mind a pozitív, mind a normatív elemzés szempontjából.

\section{A KÉTKERESŐS, EGY-}

\section{ÉS KÉTGYERMEKES CSALÁDMODELL ÁLTALÁNOSSÁ VÁLÁSA}

A modern társadalmakban a gyermekek születése egyedi döntés következménye. Ahogyan azt Gál (2014) találóan megfogalmazta „az, amit a közgazdászok (...) termékenységi döntésnek neveznek, valójában terméketlenségi döntés. Az esetek zömében az ember nem arról dönt, hogy legyen-e gyereke, hanem arról, hogy ne le- gyen. A csökkenö termékenység elsösorban azt jelenti, hogy többen és tovább mennek el annak megakadályozásában, hogy gyerekük szülessen." Praktikusan fogalmazva arról van szó, hogy

- a biológiailag determinált női és férfi termékenységet tudatos családtervezéssel felül lehet írni; amikor a párok elérkezettnek látják az időt a gyermekvállalásra, akkor a nők időlegesen abbahagyják a fogamzásgátlást; szükség esetén a nők abortusz útján akadályozzák meg a nem kívánt gyermek megszületését;

- a többség szexuális orientációjától eltérő, genetikusan öröklött és/vagy tudatosan vállalt életformákat (LMBTQ, szingli-lét, aszexualitás stb.) a liberális társadalmak egyre inkább elfogadják, és nem kényszerítik ki mindenkiből a „normális” viselkedést. ${ }^{3}$

Gyermeket - ex ante - azért vállalnak a szülők, mert ez nekik boldogságot okoz, és ezt a genetikai programozottságot nem írják felül más szempontok. ${ }^{4}$ A gyermek a szülők számára önérték, közgazdasági metaforával élve, élethossziglan élvezhető tartós fogyasztási cikk. Az egyszer megszületett gyermek a szülő hátralévő évtizedeiben mindvégig örömforrás. A gyermekvállalás jelentős mértékben ma is „női” döntés, de a jelen tanulmányban a gondolatmenet egyszerüsítése érdekében családi döntésnek fogjuk tekinteni. Erre kíván utalni a mottónak választott József Attila idézet is.

Optimális anyagi körülmények között, ami persze a történelmi múltban csak nagyon keveseknek adatott meg, a női termékenység igen magas is lehet. A Habsburg monarchia császárnéja, Mária Terézia 20 és 39 éves kora között 16 gyermeket szült; a naptári évek 79 százalékában volt egy szülési eseménye. A mai Magyarországon 100 szülőképes korú nő közül kevesebb mint négy szül gyermeket egy adott naptári évben. Ez az úgynevezett szülési valószínűség, melynek pontos, számított értéke 3,87 százalék. $^{6}$ Mária Terézia példájához képest húszszoros a különbség! 
Magyarországon már egy fél évszázada az egy- és kétgyermekes család-modell a tipikus. A befejezett termékenységű (35-39 éves) nők körében már 1970-ben is csak a nők 12 százalékának volt 3 vagy több gyermeke, ez az arány 2016-ra már alig változott (8 százalék). Közismert, hogy milyen okok vezettek ide, ezért itt elegendő csak egy rövid összefoglalás.

A biológiailag „készen kínált” emberi munkavégző képesség egyre kevesebbet ér a munkaerőpiacon. Korábban természetes volt, hogy épkézláb férfiak és nők formális képzettség nélkül alkalmasak a (fizikai) munkára. A neoklasszikus közgazdaságtan kategóriáival (Becker, 1992) ezt úgy fejezhetjük ki, hogy az ipari forradalmat megelőzően a munkaerő (L) hasznossága születéstől fogva adott volt, és érdemben nem is volt növelhetö. Mi több, a gyermekek többségét már 5-6 éves korától munkára fogták - vigyáztak a jószágra és/ vagy saját kisebb testvéreikre. A városi alsó rétegek fiai inasként léptek be a munka világába, akár már 10 éves koruk előtt. Innen nézve racionális volt, ha a szülők úgy számoltak, jó a sok gyerek, mert egy gyereknek két keze van, de csak egy szája. Azután az iparosodás terjedésével minden megváltozott. Előbb a fiúkat, majd pár évtizedes késéssel a technika fejlődése a lányokat is rákényszerítette arra, hogy iskolai képzésben vegyenek részt.

Mint Nyugat-Európában sok helyen, a felső osztályok asszonyai számára de facto Magyarországon már a két világháború között is hozzáférhetővé vált az abortusz (Mink, 1991), ami ettől fogva normaképző hatással járt az alacsonyabb státusú rétegek számára is. A művi terhességmegszakítás 1956 júniusától de jure is engedélyezett. A megbízható és olcsó orális fogamzásgátló tabletta használatának elterjedése nálunk 1968-ban kezdődött. Ennek nyomán a fiatal, nem házas férfiak és nők számára szinte kockázatmentessé vált a rendszeres nemi élet és a párválasztás határidejének meghosszabbítása. A gyermekek időzítésének és számának tervezhetősége (föként a nők számára, de kisebb mértékben a férfiak számára is) azt is eredményezte, hogy megnőtt az egyetemi továbbtanulás relatív haszna, mert nem kell azzal számolni, hogy egy váratlan terhesség miatt félbe kell szakítani a tanulmányokat. ${ }^{7}$ Mindeközben a családtervezést ellenző, tételes vallások követőinek száma folyamatosan csökkent, így egyre kevesebb nő és férfi érez büntudatot a fogamzásgátlás új technikái miatt. A vallásosság gyengülését tükrözi az is, hogy nálunk a gyermekek 45 százaléka házasságon kívül születik.

Miután a tanulás miatt a kenyérkereső kor elérése is kitolódott, szükségszerü, hogy a családalapítás is későbbre halasztódjon. Ez a változás viszont szembe ment az evolúciós logikával. A párok olyan életkorban akarnak gyermeket vállalni, amikor már túl vannak az orvosi szempontból optimális életkoron. Az orvostudomány már régóta tisztában van azzal, hogy a megtermékenyülés valószínűsége miképpen és miért csökken a nőknél 30 éves kor után, arra vonatkozóan azonban kevesebb tudományos ismeret áll rendelkezésre, hogy a középkorú férfiak nemzőképessége miért és milyen meredekséggel romlik -, de hogy ez így van, az tény. Az is jól ismert, hogy a szülők 20 as éveinek elmúltával exponenciális ütemben nő annak a valószínűsége, hogy a megfogant gyermek súlyos betegséggel jön majd a világra. ${ }^{8}$ Ez az a jelenség, amit a köznyelv úgy nevez, hogy a "párok kifutottak az időből”. ${ }^{9}$

Gyakori érv, hogy a kérdőíves felmérés- sel megbecsült kívánatos gyerekszám és a családokban ténylegesen megszületett gyermekek száma között van egy jelentősnek mondható eltérés, ${ }^{10}$ és ebből többen azt a következtetést vonják le, hogy állami támogatással ez a rés megszüntethető. ${ }^{11}$ Ezzel a logikával két baj is van. Egyfelől az emberek hajlamosak 
a kikérdezések során azt a választ adni, amiről azt gondolják, hogy ilyen a többség véleménye is. Másfelől pedig természetesnek kell tekintenünk, hogy az emberek túlnyomó többsége élete során vágyainak jelentős részét soha nem tudja kiteljesíteni. Ha azt kérdeznék az utca emberétől, hogy hány szobás lakást szeretne, évente hányszor szeretne szabadságra menni, vagy azt, hogy önmaga számára mekkora keresetet tartana igazságosnak, akkor is hasonló arányú eltérést tapasztalnánk a szándékok és a megvalósult valóság között. Ezt a tipikus élethelyzetet adja vissza zseniális tömörséggel Karinthy Frigyes jól ismert novellája, a Találkozás egy fiatalemberrel. Kornai terminológiája szerint pedig arról van szó, hogy az emberek aspirációi, az élettől való elvárásai egyidejűleg elvileg sem teljesülhetnek, hiszen egymásnak ellentmondó célokról van szó. ${ }^{12}$ Mária Terézia császárné példája ezen a ponton is visszaidézhető: az uralkodónő anyaságát dadák, szakácsnők, mosónők hada segítette, így és ezért tudta összeegyeztetni sokféle életcélját, feladatát.

Sokan hajlamosak azt feltételezni, hogy a sokgyermekes életforma választása etnikai ügy. Ilyenkor Magyarországon a romák helyzetére szoktak hivatkozni - tévesen. Nem lehet elég sokszor elmondani (Husz, 2011), hogy a „cigány” születésszám alapvetően a szegénység/ képzetlenség függvénye.

Az Egyesült Államokban nagy irodalma van az egyenlötlenségek azon fajtájának, amely a párválasztási szokások változásával függ össze. A lényeget tekintve itt egy évszázadok óta ismert jelenségről van szó, arról, amit a magyar népnyelv valaha úgy hívott, hogy „suba a subához, guba a gubához”. Manapság nem erről a tradicionális képletről van szó, hanem arról, hogy megnőtt a diplomás nők aránya, s ennek nyomán egyre nagyobb a statisztikai valószínűsége annak, hogy hasonló szinten iskolázott férfiak és nők bútoroznak össze. ${ }^{13}$ Ha viszont a házasság évei során a sok gyermeket vállaló feleség a munkapiacról való viszszavonulás miatt ${ }^{14}$ leamortizálja saját humántőkéjét, akkor nagyon megnőhet a különbség a házasfelek között a tudás, a műveltség és a társadalmi presztízs terén, ami azután visszahathat a házasság minőségére is. Emiatt természetesnek kell tekinteni, hogy kevés nő hajlandó feladni karrierjét és a „f”állású anyaságot” választani - jól lehet: ahhoz, hogy elegendő számú harmadik, negyedik és ötödik gyermek szülessen egy családban, valójában sokkal több fóállású anyára lenne szükség.

7Ritkán esik szó arról, hogy megnőtt az időbeli távolság a fiatal nemzedék családalapítása és gyermekvállalása, illetve az ő szüleik elhalálozása és a szülők által felhalmozott vagyon átöröklése között. Gyakori, hogy a „fiatalok" 60 éves korukon túl jutnak hozzá a felhalmozott családi vagyonhoz, így ez a vagyon - éppen, amikor a legnagyobb szükség lenne rá - nem tud érdemben segíteni a gyermekvállalással kapcsolatos anyagi terheken. Különösen erőteljes formában érvényesül ez az ellentmondás a lakáspiacon - és nem csak Budapesten, de Bécsben és New Yorkban is.

\section{AZ EGYÉNI HASZNOK ÉS KÖLTSÉGEK TERMÉSZETE}

E tanulmány fó állítása az, hogy a gyermekvállalási döntést a szülők a hasznok és a költségek figyelembevételével hozzák, viszonylag kisszámú alkalommal. Másképpen fogalmazva: a gyerekszámról való döntés mindig határdöntés, de nem szokványos rutindöntés, hanem - Kornai (1971) Anti-equilibriumának terminológiáját használva - úgynevezett alapvető döntés. ${ }^{15} \mathrm{Ez}$ a döntés a határhasznok és a határköltségek alaposan megfontolt összevetése nyomán születik, amikor is egy férfi és egy nő 
a gyermektelen állapotból átlép az egygyermekes állapotba, majd az egygyermekes állapotból a kétgyermekes állapotba, a kétgyermekes állapotból a háromgyermekes állapotba stb.

$\mathrm{Az}$ 1. ábrán a gyermekvállalás egyéni határhasznait (marginal utility, MU) és (nettó) határköltségeit (marginal costs, MC) vetjük össze a szülők szempontjából, rövid távon, az első gyermek születésétől az utolsó gyermek felneveléséig. Azt az átlagos helyzetet ábrázoljuk, hogy egy mai magyar családban a gyermek(ek) felnevelése, taníttatása, önálló életük elkezdése kb. 30 évet vesz igénybe.

Elemzési módszerünk végletesen leegyszerüsített. Hasznosságokat és költségeket vetünk össze, de egyik tételt sem fogjuk pénzben kifejezni („forintosítani”), vagyis a különböző té- teleket meg sem próbáljuk aggregálni. A pénzt csak pénzzel, a boldogságot csak a boldogsággal fogjuk összevetni.

A köznapi gondolkodás számára természetes feltételezés, hogy a szülők minden gyermeküket egyformán szeretik. Ez azonban csak ex post érvényes - a már megszületett gyermekekre. A jelen tanulmány megközelítése ettől különbözik. Abból indulunk ki, hogy a szülők számára, ex ante az első, egészséges gyermek megszületése hatalmas boldogság. Elsődlegesen ez az a haszon, amiért vállalkoznak gyermeknemzésre. ${ }^{16}$ Ennek a boldogságnak a nagyságát tekintjük egységnyinek, azaz 1-nek. Ehhez képest, a második gyermek megszületése már jóval kisebb pótlólagos öröm. És még ennél is kisebb a harmadik gyermek születésé-

\section{A GYERMEKVÁLLALÁS EGYÉNI HATÁRHASZNAI ÉS NETTÓ HATÁRKÖLTSÉGEI} (1. GENERÁCIÓ)

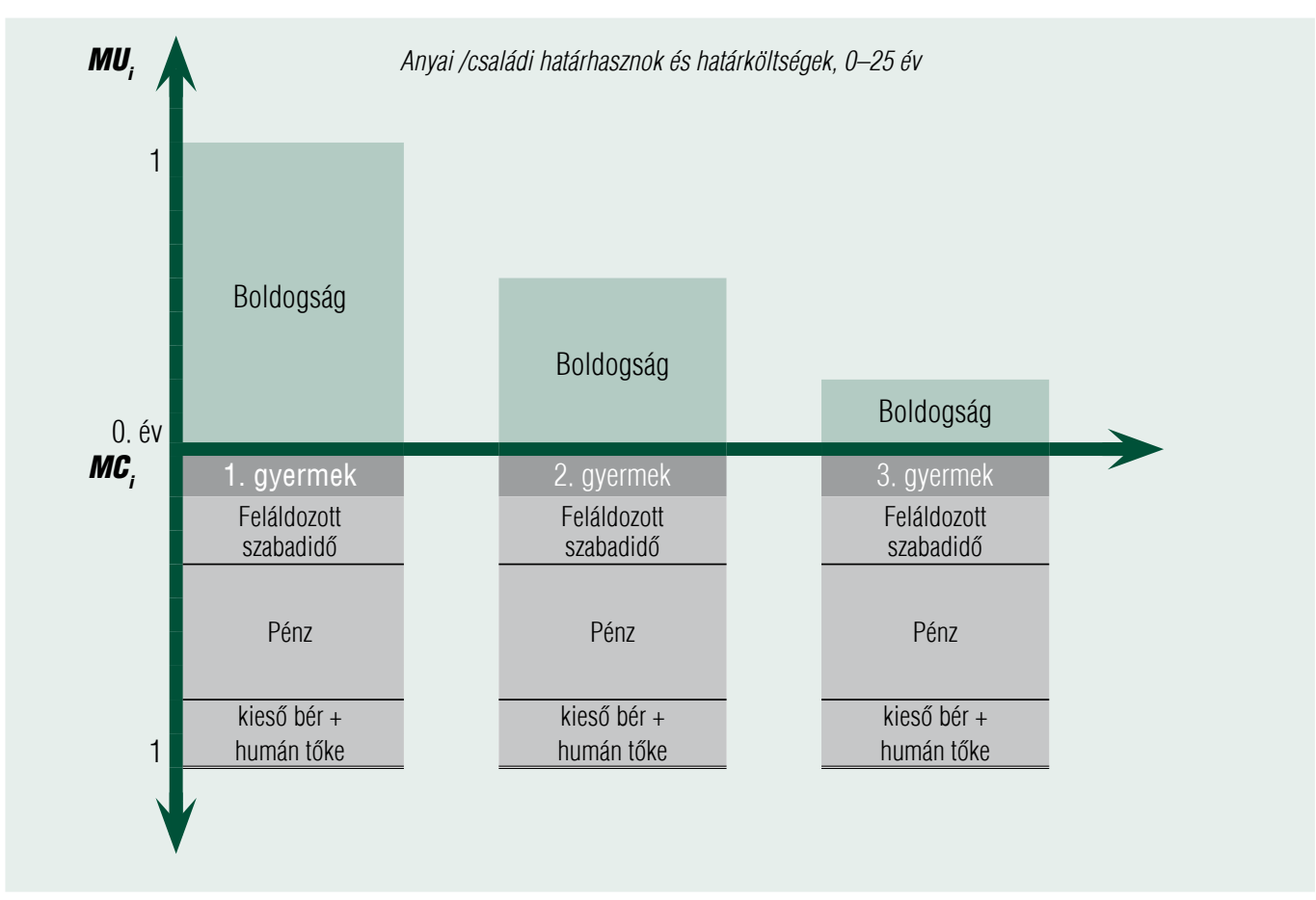

Forrás: saját szerkesztés 
vel járó határhaszon, bár felmérések azt bizonyítják, hogy két azonos nemű gyermek után a szülők sok esetben azért az örömért vállalkoznak a harmadik gyermek nemzésére, hogy a két fiú mellé szülessen egy lány is, illetve fordítva. ${ }^{17}$ Ezt a képet még tovább bonyolít(hat)ja az újraházasodás növekvő gyakorlata, amikor már gyermekkel rendelkező anyák vagy apák a második kapcsolatukból is szeretnének gyermeket vállalni (hiszen új családot alapítottak) - ez az alaphelyzethez képest megnövelheti a 2. és 3. gyermek határhasznát. Önmagában az, hogy a jelen tanulmányban monoton csökkenő hasznossági függvényt feltételezünk, semmi különleges nincs - az egyensúlyi modellek majdnem mindig ezzel a feltételezéssel élnek. ${ }^{18}$ Azt tekintjük újszerü megközelítésnek, hogy ezt a csökkenő függvényt nagyon meredeken csökkenőnek feltételezzük, mert azt a mai magyar élethelyzetet modellezzük, amikor a családok többsége eleve nem tervez 3-4-5 vagy annál is több gyermeket.

A boldogságon kívül minden más körülményt a nettó költségek oldalán veszünk figyelembe, így tehát az összes pénzbeli (készpénzes) és természetbeni juttatást, adókedvezményt stb. is, amit a családok kapnak. És persze a költségek oldalán jelennek meg a gyermekneveléssel járó pénzbeli költségek, a szülők feláldozott szabadideje, továbbá a gyermek(ek) nevelése miatt kieső (többnyire női) munkabér. A költségek egy része több gyermek esetében megspórolható (a ruházat egy része többször felhasználható, két gyermekkel játszani nem igényel több időt, mint eggyel stb.), de ezek aránya az összköltségen belül elhanyagolható. A magyar viszonyok között, amikor az anyák már 50 éve (!) minden gyermekük után 3 évig jogosultak otthon maradni, fontos költségtétel az, hogy a munkából való többéves kiesés számottevő humántőke-veszteséget jelent, ami azután megnehezíti az újbóli munkába állást, és ami végső soron alacsonyabb életpálya-jövedelemben és nyugdíjban mutatkozik meg. A koc- kázatokat is egyfajta költségtényezőnek tekintjük. Amikor a szülők a második és harmadik gyermek vállalása mellett döntenek, akkor figyelembe veszik azt is, hogy két vagy ennél is több gyermek esetén a házasság felbomlása, a válás mindkét felet nagyon nehéz helyzetbe hozza. A gyermek(ek)et egyedül nevelö szülő a megduplázódott munkateher miatt, a másik fél (többnyire a férjek) a Magyarországon meglehetősen szigorú szabályok szerint működő tartásdíj-fizetési kötelezettség miatt kerülhet krízishelyzetbe. ${ }^{19}$ Ezt mutatják a szubjektív jólét indexei is. A KSH 2016-os felmérése szerint a párkapcsolatban élők 75-76 százaléka - akár házasságról, akár együttélésről van szó, akár van gyermekük, akár nincs - önmagát boldognak vagy többnyire boldognak mondta. Az egyszülős családokban élők körében ugyanez az arány csak 55 százalék volt. ${ }^{20}$

Éppen ezért nem meglepő, hogy a válás kockázata is arra ösztönzi a nőket, hogy bennmaradjanak a munkaerőpiacon, mert ez védelmet jelent a végzetes elszegényedés ellen - ez viszont ellene hat a 3. vagy 4. gyermek bevállalásának. ${ }^{21}$ Mindezeket a tényezőket figyelembe véve az 1. ábrát úgy szerkesztettük meg, hogy világos legyen: becslésünk szerint a gyermekvállalás egyéni, nettó határköltségei a gyermekszám emelkedésével nem csökkennek (sőt az is lehet, hogy nőnek).

A 2. ábrán a gyermekvállalás ex post egyéni határhasznait és (nettó) határköltségeit vetjük össze hosszabb távon, amit 26-60 év között határozunk meg (az 1. gyermek születésétől számítva). Ezen az ábrán azokat a hasznokat és költségeket vetjük össze, amelyekkel a szülők számolhatnak azt követően, hogy gyermekeiket felnevelték. A szülők szempontjából többféle haszon is adódik, egyfelől a felnőtt gyermek léte (szakmai, emberi sikereik, boldogságuk), másfelől az unokák megszületése, felcseperedése. Bár ezt a köznapi gondolkodás ritkán szokta szavakban kifejezni, nyilvánvaló, hogy csak annak lehet unokája, akinek gyer- 


\section{A GYERMEKVÁLLALÁS EGYÉNI HATÁRHASZNAI ÉS NETTÓ HATÁRKÖLTSÉGEI (2. GENERÁCIÓ)}

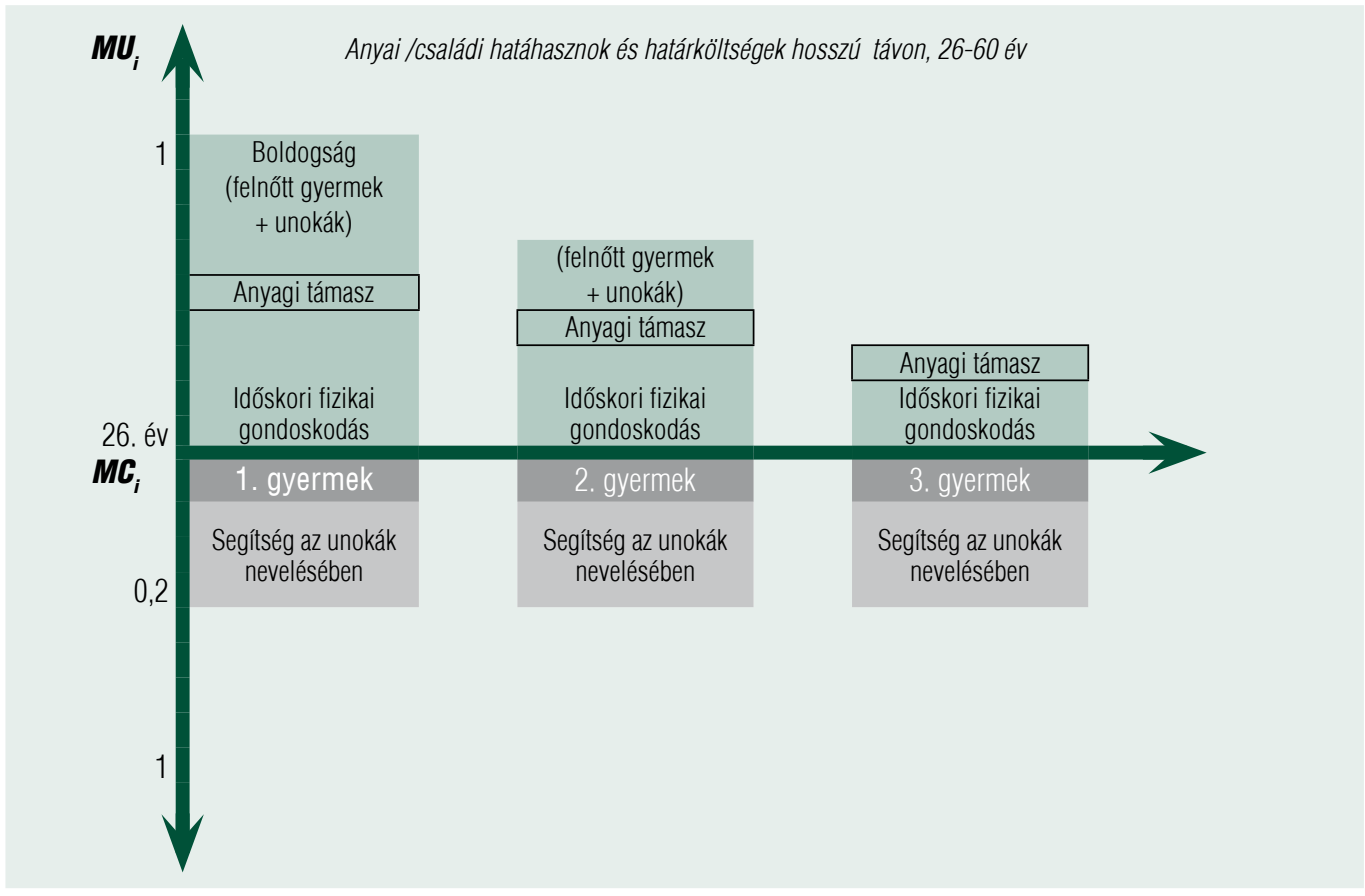

Forrás: saját szerkesztés

meke is van. Ezeket az érzelmi hasznokat egészíti - vagy egészítheti - ki az, hogy a felnőtt, kereső gyermekek képesek anyagilag is támogatni szüleiket (ha erre szükség van) és fizikai gondozásukban is tudnak segíteni. Ha a felnevelt gyermekek száma több, az a szülők számára nagyobb biztonságot ad, mintha csak egy gyermekük született volna. Egyébként az életkor kitolódásával gyakori, hogy a nagyszülőkről való fizikai gondoskodás egy részét az unokák vállalják magukra és ezzel saját szüleiket tehermentesítik valamelyest. Éppen ezért úgy becsüljük, hogy - szemben a rövid távval hosszú távon ezek a határhasznok csak kis mértékben csökkennek. Ugyanakkor azt is számba kell venni, hogy a családok többségében az egykori szülők (most már nagyszülők) részt vesznek az unokák nevelésében. ${ }^{22} \mathrm{Ez}$ időben és pénzben ráfordítással járhat - a lényeg itt is az, hogy ezek a nettó határköltségek gyermekenként nem különböznek lényegesen. Mindezek a szempontok azonban nem változtatnak azon, hogy a zömében rövid távú megfontolásokon alapuló gyermekvállalási döntéseket hosszú távon - azaz utólag - már nem lehet korrigálni.

\section{A TÁRSADALMI HASZNOK ÉS KÖLTSÉGEK TERMÉSZETE}

Nyilvánvaló, hogy a születést követő első 18 évben a gyermekek a társadalom számára csak költséget jelentenek, semmiféle közvetlen haszonnal nem járnak. Érdekes példa az amúgy meglehetősen kollektivista szellemiségű Japán, ahol a gyermekvállalást olyan mérték- 
ben tekintik egyéni, egyedi és ritka döntésnek, hogy a társadalombiztosítás alapesetben az ezzel 9 hónapon át együtt járó folyamatos ambuláns költségeket, illetve a kórházi szülés árát nem is fedezi. Intézzék ezt el a szülők a magánbiztosításuk vagy a készpénztartalékaik terhére - ez a japán közfelfogás. A 16-18 év betöltése után a kohorsz egy része elkezd dolgozni, de a többség még egy jó darabig tanul, vagyis társadalmi haszon csak a 18-29 éves korosztály munkavállalása nyomán keletkezik - méghozzá minden fiatal esetében nagyjából azonos mennyiségü haszon. Ebben a korosztályban a gyermekneveléssel járó társadalmi költségeket azonosnak vesszük minden paritás ${ }^{23}$ esetén (ami persze erős leegyszerűsítés). Ezt a helyzetet illusztrálja a 3. ábra.

Könnyen elfogadható véleménynek tűnik, hogy vannak extrém társadalmi korszakok, amikor a születendő gyermekek számának növelése minden más célt felülír. Ez a háborúk időszaka. De még ebben az esetben is igaz, hogy sok-sok év telik el attól fogva, hogy egy újszülött (fiú) hadra fogható lesz. A múltban a háborúk igen gyakoriak voltak - az egymással rivalizáló klánok, törzsek, országok úgyszólván folyamatosan háborúztak. Ezért ez a hosszú távú szempont mélyen belerögződött a társadalmak értékrendszerébe. A modern kor azonban a fejlett országok számára elhozta a tartós béke korszakát. Emiatt ez a szempont vesztett fontosságából. Általánossá vált viszont a négyöt évenként kötelező választások rendszere. A 3. ábra jól mutatja a modern kormányok dilemmáját. Nagyjából két évtizeden át a gyermekvállalás a társadalmi érdekeket „hivatal-

\section{TÁRSADALMI HATÁRHASZNOK ÉS HATÁRKÖLTSÉGEK (1. GENERÁCIÓ)}

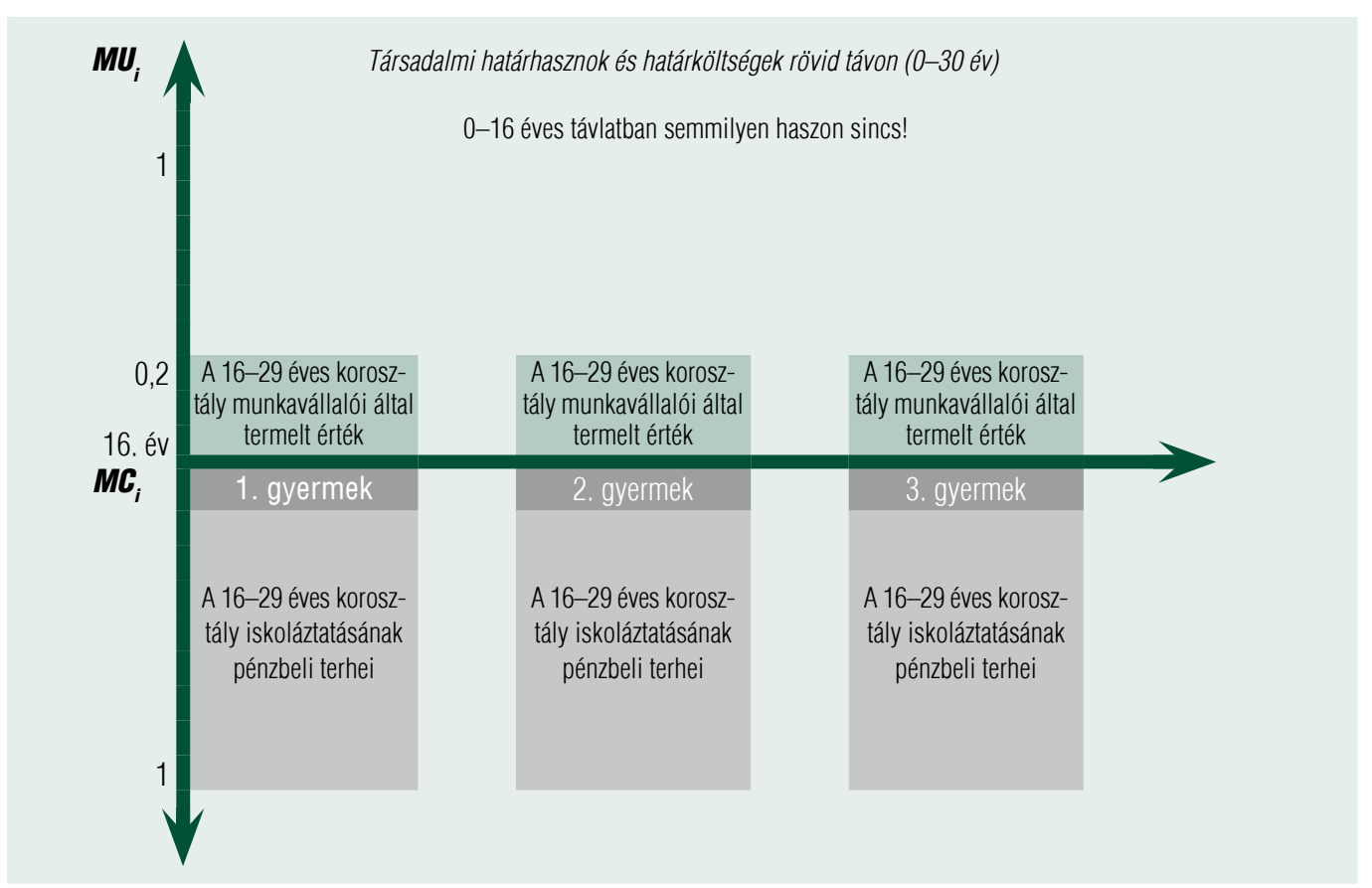

Forrás: saját szerkesztés 
ból” képviselő kormányok számára lényegesen nagyobb költséggel jár, mint haszonnal. Ezzel együtt világos, hogy kivételes esetként ma is vannak olyan országok, amelyek folyamatos háborús fenyegetettségben léteznek. Részben ez magyarázza a gazdaságilag nagyon fejlett Izrael igen magas női termékenységét $(\mathrm{TTA}=$ 2,92).

A hadászati szemponttól eltekintve napjainkban a születendő gyermekek társadalmi hasznosságát a demográfiai adatokból vezetik le a politikusok és a véleményformáló közvélemény is. De ezen belül is megfigyelhető egy hangsúlyeltolódás. A népesség abszolút számának alakulása helyett a figyelem középpontjába az elöregedés - vagyis a korosztályok közötti arány - került. A munkavállalási korban (31-65 év) a társadalom számára minden fel- nőtt gyermek értéket képvisel (azonos menynyiségüt), ezt követően viszont a 66-80 éves korosztálynak, a nem dolgozó népességnek nyugdíjat kell fizetni és a megbetegedéssel járó társadalmi költségek is meredeken emelkednek az életkorral. Másfelől viszont nyugdíjas korban a társadalom számára a hasznok között érdemes számba venni azt, amit a nagyszülők hozzájárulása az unokák nevelésében a családok számára jelent (lásd 4. ábra). Összességében tehát jól látszik, hogy ilyen hosszú távon (az 1. gyermek születése utáni 31. évtől a szülők haláláig) minden egyes megszületett gyermek társadalmi határhaszna jelentősen meghaladja a határköltségeket.

Van még egy szempont, aminek ma még lehetetlen megbecsülni a politikai relevanciáját. A nagyon hosszú távú társadalmi érdek-

\section{TÁRSADALMI HATÁRHASZNOK ÉS HATÁRKÖLTSÉGEK \\ (2. GENERÁCIÓ)}

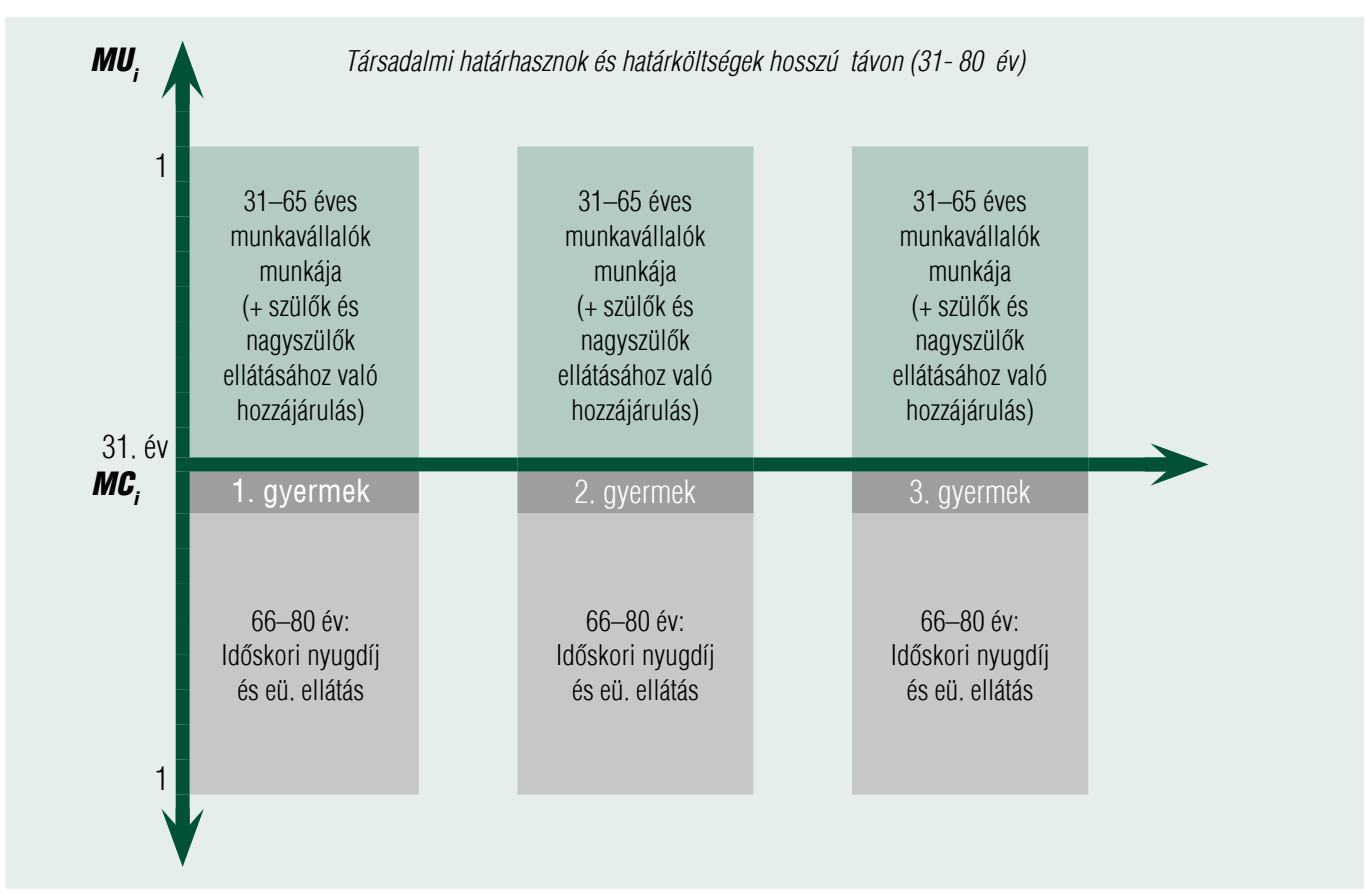

Forrás: saját szerkesztés 
kel kapcsolatos ökológiai indíttatású társadalmi diskurzus sokakban felvetette azt a kérdést, hogy szabad-e gyereket vállalni, amikor a Föld egyre növekvő népessége a kimerülő természeti tartalékokat még szűkösebbé, a klímaváltozás okozta problémákat - mint a potenciálisan felmerülö élelmiszer- és vízhiány, klímamigráció és így tovább - még súlyosabbá teheti. Nemzetközi szinten ezt az ideológiát képviseli az Angliából elindult BirthStrike mozgalom. ${ }^{24}$ Sőt lehet úgy is érvelni (Kapelner, 2019), hogy a gazdasági növekedésnek le kell állnia, ezért a ma születő gyerekek életszínvonala esetleg jóval alacsonyabb lesz, mint a miénk. Gyermekeinknek sosem látott hőmérsékleti ugrások, szárazságok, víz- és élelmiszerhiány közepette kell leélniük életüket. Ha ez így van, szabad-e kitennünk őket ezeknek a megpróbáltatásoknak azáltal, hogy életet adunk nekik. Mihályi Dávid (2019) érvelése szerint a mai szülők nemzedékének csak annyi gyermeket szabadna bevállalni, amennyiről feltételezni lehet, hogy környezettudatos viselkedésével saját széndioxid-kibocsátását a jelenlegi magyar átlaghoz képest csökkenteni fogja - vagyis összességében a sok újonnan született gyermek sem fogja rontani a Föld klímaegyensúlyát.

\section{KÖVETKEZTETÉSEK}

A jelen tanulmányban azt jártuk körbe, hogy miért születik viszonylag kevés második, harmadik és negyedik gyermek a mai magyar családokban. A határhasznok és a határköltségek fogalmának alkalmazásával arra a következetésre jutottunk, hogy a 2. és 3. gyermek egyéni határhaszna rövidebb és hosszabb távon egyaránt jóval kisebb, mint az 1. gyermeké, miközben a határköltségek az első két évtizedben biztosan nem csökkennek. A 2. és 3. gyermek társadalmi határhaszna a 16-29 éves korosztályt tekintve rövidebb távon állandó, de nagyságát tekintve kicsi. A határköltségek viszont mind rövidebb, mind hosszabb távon lényegében azonosak. A probléma lényege az, hogy a 2 . és 3. gyermek vállalása mellett mind rövidebb, mind hosszabb távon kevés érv szól az egyén szempontjából.

Ezt a bias- $\mathrm{t}$ - békeidőben, fenntartható módon - sem pénzzel, sem természetbeni társadalmi ráfordításokkal nem lehet ellentételezni - különösen akkor nem, ha a potenciálisan érintett állampolgárok jelentős része nem is ismeri a családtámogatási rendszert, másfelől akik ismerik, azok sem bíznak a tartósságában (Ignits, Kapitány, 2006), és/vagy a kormány által elgondolt támogatási eszközt alkalmatlannak tartják. Ez utóbbira vonatkozóan fontos figyelmeztetést tartalmaz az Állami Számvevőszék (2019, 10. o.) friss jelentése, amely egy 2017-es, a felsőoktatásban részt vevő tanulók kérdőíves felmérése alapján arra hívja fel a döntéshozók figyelmet, hogy a megkérdezett fiatalok 76 százaléka (!) szerint az otthonteremtési támogatások lényegesen nem, vagy egyáltalán nem befolyásolják a gyermekvállalási kedvet. Akármekkora összegeket is fektet az állam családpolitikai támogatásokba, ezektől hosszú távú népesedéspolitikai hatást csak akkor várhatunk, ha az állami szabályozás logikája fó vonalakban egyezik a tudományosszakmai közvélemény álláspontjával, és ezért nincsenek körülötte éles politikai viták.

Némileg meglepő módon a Hétfa Kutatóintézet (2019) ökonometriai elemzése azt mutatta, hogy a Magyarországon kipróbált, különféle családtámogatási rendszereknek öszszességében véve rövid (0-3 éves) távon is igen alacsony a hatása a TTA-ra és a szülési valószínűségekre. Különösen akkor, ha azt is figyelembe vesszük, hogy számos kormányzati intézkedés „csak” arra jó, hogy a már egyébként is tervezett, első vagy második gyermek születését időben előbbre hozza. ${ }^{25}$ Számításaik szerint a családi adókedvezmény öszszegének 10 százalékos növelése - ami igen jelentős ráfordításnövekedést jelentene - vár- 
hatóan csak annyi változást eredményezne, hogy (adottnak véve a szülőképes korban lévő nők számát) a „többletgyermekek” születésének valószínűsége 3,87 százalékról 3,97 százalékra nőne.

\section{Egy irreális disztópia}

Az egyéni és a közösségi érdek összehangolása minden korban bonyolult társadalmi mechanizmusokat igényelt. A munka esetében hoszszú-hosszú évezredeken át az erőszakra épülő társadalmi konvenciók domináltak. Később ennek helyét a bérmunka vette át. A hadviselés, részben a piaci mechanizmus felhasználásával folyt - az uralkodók zsoldosokat alkalmaztak. A másik lehetőség a kötelező sorozás intézménye volt. A társadalombiztosítás rendszerében való részvétel a legtöbb országban törvényi kötelezettség. Mint bemutattuk, a gyermekszám csökkenése végső soron azzal áll közvetlen kapcsolatban, hogy nincs háborús fenyegetés, könnyen hozzáférhető a fogamzásgátlás, a nők kitolódott tanulmányi ideje miatt későbbre halasztódik az első gyermek megszületése, és az is elfogadott, hogy egy nő ne is akarjon gyermeket szülni.

Gondoljuk végig, lehetséges-e mai viszonyaink közepette olyan jogszabályokat hozni, amelyek épp ezeket a folyamatokat szándékoznak visszájára fordítani. Vagyis: megtiltják a fogamzásgátlás korszerű formáit és elzárják a nőktől a továbbtanulás lehetőségét. Nyilvánvaló, hogy bármely kormány, amely ezzel kísérletezne, elvesztené a soron következő választást, de még az is lehet, hogy a tüntető népharag napokon belül elsöpörné. Ha mégsem ez történne, akkor a nők jelentős része a külföldre vándorlást választaná már az általános iskola 8. osztálya után. Summa-summárum: a TTA csökkenése visszafordíthatatlan.

1. táblázat

\section{A CSALÁDOKRA KÖLTÖTT KÖLTSÉGVETÉSI JUTTATÁSOK A GDP SZÁZALÉKÁBAN, 2015}

\begin{tabular}{lc|c|} 
& Ország & Százalếk \\
\hline Svédország & 3,5 \\
\hline Egyesült Királyság & 3,5 \\
\hline Franciaország & 3,0 \\
\hline Magyarország & $\mathbf{3 , 0}$ \\
\hline Csehország & 2,0 \\
\hline Szlovákia & 2,0 \\
\hline Lengyelország & $1,5^{\star}$ \\
\hline Izrael & 1,9 \\
\hline USA & 0,6 \\
\hline OECD-átlag & 2,0 \\
\hline
\end{tabular}

Megjegyzés: Pénzbeli és természetbeli támogatások együtt. A számba vett tételek között a gyermekek után járó adókedvezmény nincs figyelembe véve. Ez - éppen Magyarország esetében - jelentős alulbecslést eredményez.

*2014

Forrás: OECD: Family benefits public spending, https://data.oecd.org/socialexp/family-benefits-public-spending.htm\#indicator-chart, letöltés 2019. jún. 30-án. 
Kiknek kedvez a pronatalista

kormányzati politika?

Magyarországon a gyermekvállalás ösztönzése érdekében alkalmazott intézkedések - a bölcsődei/óvodai férőhelyek létesítésétől, a lakáspolitikán keresztül az adókedvezményekig és a mindenféle pénzbeli juttatásig - mind az érintettek, mind a közvélemény szemében általában népszerüek. Ám van itt egy félreértés: az állami segítség csak arra alkalmas, hogy a gyermekvállalással összefüggő terhek nyomán kialakuló jövedelmi és vagyoni egyenlőtlenségeket - ceteris paribus - enyhítse (Gál, 2014; ÁSZ 2019), de arra nem, hogy tartósan növelje a termékenységet. Mint az 1. táblázatból látszik, a Magyar Állam nemzetközi összehasonlításban már ma is sokat költ családtámogatásra - lényegesen többet, mint az OECD-átlag.

De van egy további súlyos probléma is: a hazai családtámogató rendszerek elmúlt 10 évben alkalmazott formái erősen pro-rich hatásúak voltak, vagyis azonos gyermekszám esetében a magasabb jövedelmű és vagyonú családoknak kedveztek. A Hétfa Intézet 2000-2014-re vonatkozó vizsgálata azt is kimutatta, hogy a családpolitikai ráfordítások - az átlagosan igen alacsonynak mondható pozitív összhatás mellett - leginkább a nyugati megyékben, a magas végzettségü, 30-40 év közötti asszonyok gyermekvállalására hatottak.

Ugyanez mondható el a 2019. július 1-től érvényes új konstrukciókra. Egyes frissen készült pénzintézeti hatásszámítás szerint ${ }^{26}$ egy jómódú, 700 ezer forint együttes havi nettó jövedelemmel rendelkező család amennyiben 4 gyermeket vállal, új ingatlant vásárol és ehhez 15 millió forint támogatott (CSOK) hitelt vesz igénybe, közel 50 millió forint viszsza nem térítendő állami támogatáshoz juthat. Amennyiben egy olyan 30 év körüli házaspár vállal 4 gyermeket, ahol a férj egyetlen mun- kajövedelme a közmunka, a feleség gyesen van és nincs megtakarításuk, akkor ők semmiféle hitelhez és támogatáshoz nem juthatnak sem új, sem használt ingatlant nem tudnak vásárolni. Így a vissza nem térítendő támogatás 0 forint lesz az ő esetükben. Ha pedig egyetemisták házasodnak össze, két gyermeket vállalnak, de még nincs önálló jövedelmük, ám 10 millió forint hitelt vesznek fel egy használt lakás megvásárlásához, akkor csak 3,2 millió forint költségvetési támogatást kaphatnak. Ehhez járul még az a 2,5 millió forint támogatás, amelyet a nagycsaládosok egy új, hétszemélyes autó vásárlásához kapnak - ez is nyilván csak a kivételesen magas jövedelmű nagycsaládosok számára jelent majd ténylegesen igénybe vehető támogatást.

\section{Nemzeti keretek között nem érhető el az optimum}

Szemben a neoklasszikus egyensúlyi modellekkel, amelyekben az egyéni/családi életstratégiák optimalizálása a gyermekek taníttatásába fektetett humántőke-beruházás hosszú távú hozadékán keresztül vezet el a társadalmi optimumhoz, a jelen tanulmány legfontosabb következtetése az, hogy a tanulmányban figyelembe vett tényezők keretein belül nem jön és nem is jöhet létre az egyensúly. Egyéni szinten természetesen „valahogyan” minden nő és minden család össze tudja hangolni a munkavállalást és a gyermeknevelést (akár úgy is, hogy nem vállalnak gyermeket), de a jól mérhető, stabil tendenciák nem vezetnek társadalmi optimumhoz: a népességfogyás és az elöregedés nem szűnik meg. Nemzeti keretek között a pronatalista kormányzati politika ezen a helyzeten csak kismértékben tud változtatni, és azt is csak a társadalmi egyenlőtlenségek növelése árán. 


\section{JEGYZETEK}

${ }^{1}$ E cikk első változatához füzött megjegyzésekért köszönettel tartozom Banyár Józsefnek, Kovács Erzsébetnek, Simonovits Andrásnak és SzabóMorvai Ágnesnek, továbbá a folyóirat anonim lektorának. Nyilatkozat: A tanulmány elkészítéséhez közvetlen anyagi támogatást sehonnan sem kaptam.

2 Érdemes megemlíteni, hogy az Egyesült Államokban, ahol nincs szövetségi szintü törvény a szülési szabadság intézményére, 2018 óta éppen a fordított ötlet van napirenden. A Marco Rubio szenátor és Ivanka Trump nevéhez kapcsolódó törvényjavaslat azt célozza, hogy a fiatal anyák saját öregségi nyugdíjuk terhére vehessenek igénybe 2 hónapos, fizetett szülési szabadságot - eltolva ezzel a nyugdíjbavonulás időpontját. https://www. vox.com/2018/8/6/17648462/rubio-ivankarepublican-paid-leave

3 Itt és a továbbiakban figyelmen kívül hagyjuk a statisztikai számosság szempontjából külön-külön nem nagy vagy egyenesen elhanyagolható jelentőségü egyéb lehetőségeket (spontán abortusz, férfi és női meddőség, örökbefogadás, béranyaság, ikerterhesség, nemi erőszak, csecsemőgyilkosság, fel nem ismert terhesség stb.)

${ }^{4}$ Holtzer (2012) 134. o.

5 Mészáros (2012), 9. o.

${ }^{6} \mathrm{Ez}$ az ún. szülési valószínűség, melynek pontos, számított értéke 3,87. Hétfa Kutatóintézet (2019).

7 Goldin, Katz (2002) tanulmánya bemutatja, hogy ez az oksági kapcsolat az 1960-as évek közepétől kezdve milyen speciális okok miatt volt különösen erős az Egyesült Államokban. Egyfelől a csak receptre felírható orális fogamzásgátlók terjedését nagyban elősegítette a nagykorúság alsó határának leszállítása 18 éves korra (vagyis nem volt szükség többé szülői beleegyezésre), másfelől ekkor már lezajlott az egyetemi/fóiskolai kapacitások jelentős kibővülése, aminek pozitív hatását addig jobbára a fiúk élvezték. Azután, mint annyi más területen, e téren is érvényesült az amerikai életmodell mintaadó hatása a fejlett világ minden más országában.

${ }^{8}$ Egy 20 éves nő esetében annak a valószínüsége, hogy gyermeke Down-kórral születik 1:525-höz, egy 40 éves nő esetében 1:65-höz. https://www. womenshealthmag.com/health/a21563046/bestage-to-have-a-baby/

9 Arra is sok példa van, hogy a stabil párkapcsolatot kereső férfiak és nők, miután túl hosszú ideig éltek egyedül, el sem jutnak abba az helyzetbe, hogy kiderüljön van-e medikális korlátja a gyermekvállalásnak. Az mindenesetre tény, hogy 2001 és 2011 között a gyermektelenek aránya a 41-45 éves magyar asszonyok között 7,8 százalékról 11,2 százalékra nőtt. Szélsőséges példaként érdemes megemlíteni, hogy ez a probléma a Magyarországnál sokkal gazdagabb Japánban még erőteljesebben jelentkezik: a 18-39 éves nők korosztályában 2015-ben a kohorsz 24,6 százalékának egyáltalán nem volt semmiféle heteroszexuális kapcsolata, a férfiaknál ez az arány 25,8 százalék volt. Ghaznavi és szerzőtársai (2019).

${ }^{10}$ Az ideális gyermekszám értéke 2016-ban 2,2 mind a nők, mind a férfiak körében, a tervezett gyermekszám értéke pedig átlagosan 2,0 a nők és 1,9 a férfiak körében.

${ }^{11}$ Spéder, Kapitány (2007). A legfrissebb irodalomból ld. Állami Számvevőszék (2019), KINCS (2019), Koncz (2019)

${ }^{12}$ Kornai (1971) 214. oldal 
${ }^{13}$ A biológiában ezt hívják nemvéletlen alapú párválasztásnak, vagy idegen szóval homogámiának. A társadalomtudományban használatos angol nyelvű kifejezés: assortative mating. Lásd Mihályi, Szelényi (2016).

${ }^{14}$ A három éves GYES-t 1967-ben vezették be; a közvéleménynek azt mondták, hogy ezzel is a gyermekvállalást kívánja bátorítani a kormány. Ez a tévképzet ma is él (Állami Számvevőszék, 2019, 5. o.). Csak a beavatottak szűkebb köre tudta, hogy valójában ez a lépés az 1968-as gazdasági reform része volt. A kormány ugyanis azt feltételezte, hogy a reform hatására a vállalatok tömegesen fogják elbocsátani a képzetlen, fiatal nőket - legyen számukra az elörehozott gyermekvállalás a közvetlen menedék.

${ }^{15}$ Lásd Kornai (1971). 9.3., 10.4., 13.4., 14.6. alfejezet. A kétfajta döntés megkülönböztetésének jelentőségéről lásd Mihályi (2013).

${ }^{16}$ Természetesen az állítás fordítottja is igaz: a gyermektelenségnek óriási költségei (disutility) vannak az egyének számára mind rövid, mind hosszú távon.

${ }^{17}$ Számos kultúrkörben a fiúgyermeket értékesebbnek tartják, mint a lányokat - ez a torzítás a mai Magyarországon is létezik, de marginális jelentőségü.

${ }^{18}$ Ilyen csökkenő határhasznot feltételező modell szerepel Németh $(2016,2017)$ írásaiban is.
${ }^{19}$ A válás kockázata igen számottevő, és ezt - ha nem is a demográfiai kategóriák nyelvén kifejezve - az emberek pontosan tudják is. 2016-ban a gyermekes családok között közel 30 százalék volt az egyszülős családok aránya. Az ilyen családok 24 százalékában élt kettő, 7 százalékában három vagy annál több gyermek. A gyermekek egyedülálló szülőként való nevelése fóként az anyákra hárul, az összes egyszülös családon belüli részesedésük megközelítette a 86 százalékot.

${ }^{20}$ A 2016-os mikrocenzus adatait idézi KSH (2019) 207. oldal

${ }^{21}$ Hétfa Kutatóintézet (2019).

${ }^{22}$ Feltéve, hogy a felnevelt gyermeknek Magyarországon születik gyermeke - ami egyáltalán garantáltan magától értődő napjainkban.

${ }^{23}$ Az élveszületési sorrend szaknyelvi megnevezése.

${ }^{24}$ Wynes, Kimberly (2017) szerint, amennyiben a fejlett országok mindegyikében 1-gyel kevesebb gyermek születne az több mint 20-szor nagyobb széndioxid-termeléscsökkenést eredményezne, mint amit az jelentene, hogy a fejlődő országokban egy éven át senki nem használna gépjárművet.

${ }^{25}$ Az újabb irodalomból ld. Berde, Kovács (2016) és a Hétfa Kutatóintézet (2019) eredményeit.

${ }^{26}$ A City Hitelbróker Kft. számításait ld. a HVG 2019. jún. 27.-i számában (6-10. oldal).

\section{IRODALOM}

Becker, G. S. (1981). A Treatise on the Family. Cambridge, MA, Harvard University Press

Becker, G. S. (1992). „The Economic Way of Looking at Life", előadás a Nobel-díj átvétele alkal- mából, december 9. https://www.nobelprize.org/ uploads/2018/06/becker-lecture.pdf

Berde É., Kovács E. (2016). A svéd és a magyar termékenységi arányszám összehasonlítása, Közgaz- 
dasági Szemle, 63. évf. december, 1348-1374. oldal https://doi.org/10.18414/ksz.2016.12.1348

Demeny, P. (1987). Re-Linking Fertility Behavior and Economic Security in Old Age: A Pronatalist Reform. Population and Development Review, Vol. 13, No. 1. pp. 128-132, Magyarul: Demény Pál (2016). Népességpolitika a közjó szolgálatában, Bp. KSH Népességtudományi Kutatóintézet, 67-72. oldal, https://doi.org/10.2307/1972124

Gál R. I. (2014). Kísérlet a gyermeknevelésfüggő nyugdíjszabályokról szóló vita befolyásolására”, http://www.nepesedesikerekasztal.hu/index.php?option $=$ com_content $\&$ view $=$ article $\& i d=$ 168fb_comment_id=668262849894174_686336 111420181

Ghaznavi, C., és szerzőtársai (2019). Trends in heterosexual inexperience among young adults in Japan: analysis of national surveys, 1987-2015 BMC Public Health 19. sz. https://doi.org/10.1186/s12889-019-6677-5

Goldin, C., King, F. L. (2002). The Power of the Pill: Oral Contraceptives and Women's Career and Marriage Decisions. Journal of Political Economy, Vol. 110. No. 4., pp. 730-770, https://doi.org/10.1086/340778

Holtzer P. (2012). Mikor lesz itt gyerek és nyugdíj? Ld. Kovács (2012) 133-135. oldal

Husz I. (2011). Alacsony végzettség - sok gyerek? A magas termékenység néhány területi és etnikai aspektusáról. Demográfia, 54. évf. 1. szám, 5-22. oldal

Ignits Gy., KapitÁny B. (2006). A családtámogatások alakulása: Célok és eszközök", Demográfia, 49. évf. 4. szám, 383-401.oldal

KapelNer Zs. (2019). Szabad-e gyereket vállalni a klímaváltozás korában? https://qubit. hu/2019/04/14/szabad-e-gyereket-vallalni-a-klima valtozas-koraban

Koncz K. (2019). A gyermekvállalás társadalmi, gazdasági háttere. Magyar Tudomány, 8. sz. https://doi.org/10.1556/2065.180.2019.8.11

Kornai J. (1971). Anti-equilibrium. A gazdasági rendszerek elméleteiröl és a kutatás feladatairól. Budapest, Közgazdasági és Jogi Könyvkiadó

Kovács E. (szerk.) (2012). Nyugdij és gyermekvállalás. Tanulmánykötet, Budapest, Gondolat Kiadó

MÉszáros J. (2012). Be(fel)vezető. Gyermekvállalás és nyugdíjrendszerek. ld. Kovács (2012) 7-14. oldal

Mihályi D. (2019). Mit tegyünk, ha gyereket vállalunk a klímaváltozás korában? www. qubit.hu, május 3. https://qubit.hu/2019/05/03/ mit-tegyunk-ha-mar-gyereket-vallaltunk-aklimavaltozas-koraban

MiháLyi P. (2012). Húsz érv a nyugdíj és a gyermekszám összekapcsolása ellen. Lásd: Kovács (2012) 144-162. oldal

Mihályi P. (2013). Kornai János Antiequilibriuma mint az evolúciós közgazdaságtan szellemi előfutára. Közgazdasági Szemle, 60. évf., március, 282-289. oldal

Mihályi P., SzelÉnyi I. (2016). Az egyenlőtlenségek valódi természetéről. Mozgó Világ, 42. évf. 11. sz., 3-12. oldal

Mink A. (1991). Kis magyar abortusztörténet. Beszélo", 48. sz., nov. 30. http://beszelo.c3.hu/ print $/ 5869$

Németh P. (2016). Gyermekvállalási döntések és termékenységi idösorok 1970-tól 2011-ig. PhD-ér- 
tekezés, Budapesti Corvinus Egyetem, Általános és Kvantitatív Közgazdaságtan Doktori Iskola, https://doi.org/10.14267/phd.2016041

NÉMETH P. (2017). A gyermekvállalási döntés életciklusmodellje Magyarországon. Hitelintézeti Szemle, 16. évf. 4. sz., 5-35. oldal, https://doi.org/10.25201/hsz.16.4.535

SpÉDER Zs., KAPITÁNy B. (2007). Gyermekek: Vágyak és tények. Dinamikus termékenységi elemzések. KSH Népességtudományi Kutatóintézet, Mühelytanulmányok 6.

Wynes, S., Kimberly, A. N. (2017). The climate mitigation gap: education and government recommendations miss the most effective individual actions. Environmental Research Letters, július 12. https://doi.org/10.1088/1748-9326/aa7541
Állami Számvevőszék (2019). A családtámogatások rendszere Magyarországon, Budapest, ÁSZ

KINCS (2019). A tervezett gyermekek számának alakulása a 2010-es években, Budapest: Kopp Mária Intézet a népesedésért és a családokért. https://www. koppmariaintezet.hu/docs/KINCS\%20tervezett $\% 20$ gyermekek\%20sz\%C3\%A1 m\%C3\%A1 nak\%20 alakul\%C3\% A1sa\%2020190211_v2.pdf

KSH (2019). Magyarország 2018, Budapest

Hétfa Kutatóintézet (2019). Evaluation of family policy measures and their impact on fertility, $\mathrm{Az} \mathrm{Eu}-$ rópai Bizottság Budapesti Képviselete megrendelésére készült tanulmány, Szerző: Szabó-Morvai Á. és munkatársai, Budapest. Hétfa Kutatóintézet, https://ec.europa.eu/hungary/sites/hungary/files/ docs/hetfa_fertilitymodels_20190701.pdf 